\title{
RELEVANSI INFORMASI DALAM PENGAMBILAN KEPUTUSAN INVESTOR DI PASAR MODAL
}

\author{
Sri Handayani ${ }^{1}$, Yosevin Karnawati ${ }^{2}$ \\ Fakultas Ekonomi dan Bisnis Universitas Esa Unggul \\ Jalan Arjuna Utara No 09 Kebon Jeruk Jakarta Barat \\ sri.handayani@esaunggul.ac.id
}

\begin{abstract}
The concept of the value relevance of accounting information explains how investors react to the announcement of accounting information as an important consideration in the investment decision making process. The purpose of this study is to analyze relevant information on the capital market indicated by influence of leverage, working capital turnover, firm size, and profitability on firm value. The population in this study is the food and beverage sub-sector manufacturing industry which is listed on the Indonesia Stock Exchange (IDX) from 2015 to 2019 with a total of 80 companies. The sampling technique in this study used a purposive sampling technique, so that the criteria were companies that were consistently listed on the IDX during the study year. The research data amounted to 70 data. The research design in this study uses a causal design. The data analysis technique used is multiple linear regression analysis. The results of the study found that leverage, working capital turnover, company size, and profitability simultaneously affect firm value. Leverage and working capital turnover partially have no effect on firm value. Meanwhile, firm size and profitability partially have a positive effect on firm value. The conclusion of this study explains that large companies have better control over market conditions, so that they are able to face economic competition, thereby being able to generate large profits. Profitability is good news for investors.

Keywords : Leverage, Working Capital Turnover, Company Size, Profitability, Firm Value
\end{abstract}

\begin{abstract}
Abstrak
Konsep relevansi nilai informasi akuntansi menjelaskan tentang bagaimana investor bereaksi terhadap pengumuman informasi akuntansi sebagai pertimbangan penting dalam proses pengambilan keputusan investasi. Tujuan dari penelitian ini adalah penganalisis pengaruh leverage, perputaran modal kerja, ukuran perusahaan, dan profitabilitas terhadap nilai perusahaan.

Populasi dalam penelitian ini adalah industri manufaktur sub sektor makanan dan minuman yang terdaftar di Bursa Efek Indonesia (BEI) tahun 2015 sampai dengan 2019 dengan total 80 perusahaan. Teknik pengambilan sampel dalam peneltian ini menggunakan teknik purposive sampling, sehingga dengan kriteria perusahaan yang konsisten terdaftar di BEI selama tahun penelitian. Data penelitian berjumlah 70 data. Desain penelitian pada penelitian ini menggunakan desain kausal, yaitu hubungan sebab akibat. Teknik analisis data yang digunakan adalah analisis regresi linier berganda.

Hasil penelitian menemukan bahwa variabel leverage, perputaran modal kerja, ukuran pperusahaan, dan profitabilitas secara simultan berpengaruh terhadap nilai perusahaan. Leverage dan perputaran modal kerja tidak berpengaruh terhadap nilai perusahaan. Sedangkan ukuran perusahaan dan profitabilitas berpengaruh positif terhadap nilai perusahaan. Kesimpulan dari penelitian ini menjelaskan bahwa perusahaan besar memiliki kontrol yang lebih baik terhadap kondisi pasar, sehingga mereka mampu menghadapi persaingan ekonomi, dengan demikian akan mampu menghasilkan profit yang besar. Profitabilitas yang besar merupakan sinyal baik bagi para investor.

Kata Kunci : Leverage, Perputaran Modal Kerja, Ukuran Perusahaan, Profitabilitas, Nilai Perusahaan
\end{abstract}

\section{Pendahuluan}

Perusahaan adalah salah satu pengembang ekonomi di negara-negara di dunia pada saat ini (Seviana, 2018).
Perusahaan didirikan jelas, yaitu untuk maksimal atau laba Tujuan perusahaan memiliki tujuan yang mencapai keuntungan yang sebesar-besarnya. yang kedua adalah 
memakmurkan pemilik perusahaan atau para pemilik saham. Sedangkan tujuan perusahaan yang ketiga adalah memaksimalkan nilai perusahaan yang tercermin pada harga sahamnya. (Agus dan Martono, 2017) Faktor terpenting dalam pembentukan sebuah harga saham adalah kekuatan permintaan dan penawaran.

Informasi yang lengkap, relevan, akurat dan tepat waktu sangat diperlukan oleh investor di pasar modal sebagai alat analisis untuk mengambil keputusan investasi (Jogiyanto, 2016). Harga pasar merupakan bertemunya titik-titik kestabilan kekuatan permintaan dan titik-titik kestabilan kekuatan penawaran harga yang secara rill terjadi pada transaksi jual beli surat berharga di pasar modal antara para penjual (emiten) dan para investor, atau sering disebut sebagai ekuilibrium pasar. Oleh karena itu, dalam teori keuangan pasar modal, harga saham di pasar disebut sebagai konsep nilai perusahaan (Harmono, 2017).

Setiap pengelola perusahaan akan menunjukan kepada calon investor bahwa perusahaan mereka tepat dipertimbangkan sebagai alternatif investasi, sehingga harus dapat menyajikan informasi akuntansi yang berupa laporan keuangan secara lengkap, relevan, akurat, dan tepat waktu kepada para investor dipasar modal sebagai alat analisis untuk mengambil keputusan investasi. Informasi tersebut akan menjadi signal baik (good news) atau signal buruk (bad news) bagi investor. Peluang investasi dapat memberikan sinyal positif tentang pertumbuhan perusahaan dimasa yang akan datang, sehingga dengan meningkatnya harga saham maka nilai perusahaanpun akan meningkat (Nur Indah Sari, 2018).

$\begin{array}{crr}\text { Nilai } & \text { perusahaan } & \text { yang tinggi } \\ \text { menunjukkan } & \text { tingginya } & \text { kemakmuran }\end{array}$ pemegang saham. Fred dan Thomas (2015) mengukur nilai perusahaan dengan menggunakan Tobin's Q, yang dihitung dengan membandingkan rasio nilai pasar saham perusahaan dengan nilai buku ekuitas perusahaan. Menurut Indriyani (2017) nilai perusahaan dapat dikatakan baik apabila Tobins'q diatas satu (overvalued). Sebaliknya, apabila Tobins'q dibawah satu (undervalued) maka menunjukkan nilai perusahaan tidak baik.
Faktor yang dapat mempengaruhi nilai perusahaan antara lain adalah tingkat hutang (leverage), perputaran modal kerja, ukuran perusahaan dan profitabilitas. Rasio hutang (leverage) dalam penelitian ini diproksikan menggunakan Debt to Equity Ratio (DER) yang merupakan perbandingan jumlah pinjaman jangka panjang yang dimiliki perusahaan dengan jumlah modal sendiri. DER merupakan salah satu rasio keuangan yang mengukur seberapa besar kemampuan perusahaan melunasi utang dengan modal yang dimilikinya (Husnan, 2015). Menurut Laily (2018) jika perusahaan memiliki hutang yang besar tentu akan memberikan beban berat kepada perusahaan, sehingga semakin besar DER maka akan semakin kecil laba yang akan dibagikan kepada pemegang saham. Hal ini akan menyebabkan minat investor untuk menanamkan modalnya berkurang, sehingga akan menurunkan harga saham perusahaan dan dapat menurunkan nilai perusahaan. Hasil penelitian Laily (2018) mengatakan bahwa leverage secara langsung berpengaruh terhadap nilai perusahaan. Sedangkan hasil Penelitian Lestari (2016) mengatakan bahwa leverage tidak berpengaruh signifikan terhadap nilai perusahaan.

Kemajuan perusahaan akan seiring dengan modal yang diperlukan untuk membiayai kegiatan usahanya. Semakin besar perusahaan akan semakin besar pula modal yang dibutuhkannya. Tingkat perputaran modal kerja mengukur berapa kali aktiva lancar mampu berputar untuk menghasilkan penjualan. Semakin cepat modal kerja berputar semakin banyak penjualan yang berhasil tercipta. Tingkat perputaran modal kerja yang tinggi mengindikasikan perusahaan telah mengelola modal kerjanya secara baik dan efisien, sebaliknya tingkat perputaran modal kerja yang rendah mengindikasikan perusahaan mengelola modal kerjanya dengan buruk. Adanya perputaran modal kerja yang baik maka kegiatan operasional perusahaan pun akan berjalan dengan baik, secara tidak langsung membawa perusahaan kedalam kondisi yang menguntungkan (Christiana dan Sintje, 2016). Munawir (2015) menyatakan bahwa perputaran modal kerja menunjukkan berapa kali dana yang tertanam dalam modal kerja dan berputar dalam satu periode. Jumlah penjualan yang bisa dicapai oleh setiap rupiah modal kerja, dan 
jumlah penjualan tersebut otomatis berpengaruh terhadap profitabilitas, semakin cepat perputaran modal kerja menunjukkan semakin efektif penggunaan modal kerja yang berdampak pada meningkatnya profitabilitas perusahaan. Dengan adanya perputaran modal kerja yang tinggi perusahaan tidak akan mengalami kesulitan dan hambatan yang akan mungkin timbul di masa yang akan datang dan akan berdampak pada perolehan profit perusahaan.

Menurut Christiana dan Sintje (2016) modal kerja merupakan aspek paling penting bagi tiap perusahaan karena modal kerja merupakan faktor penentu berjalannya kegiatan operasional jangka pendek dalam perusahaan. Kegiatan operasional tersebut berpengaruh pada pendapatan yang diperoleh perusahaan. Perusahaan yang mampu menghasilkan nilai tambah atau keuntungan yang berkelanjutan (sustainable) adalah perusahaan yang mampu memanfaatkan modal kerjanya secara efektif dan efisien. Kesalahan atau tidak efektifnya pengelolaan modal kerja bisa menyebabkan menurunnya performa operasional perusahaan. Perputaran modal kerja yang tinggi menunjukkan bahwa perusahaan dapat beroperasi dengan baik dan menutup pengeluaran biaya yang ada di perusahaan (Liviawati dkk (2019). Peningkatan perputaran modal kerja akan dapat meningkatkan penjualan dan modal juga dapat kembali dengan cepat sehingga keuntungan perusahaan juga meningkat (Randhy, 2017). Semakin erat perputaran masing-masing komponen modal kerja perusahaan dan semakin banyak dana yang dapat diinvestasikan kembali ke dalam modal kerja, sehingga dapat meningkatkan profitabilitas perusahaan, berarti semakin efektif pengelolaan modal kerja perusahaan dan semakin banyak dana yang dapat diinvestasikan kembali ke dalam modal kerja. Perputaran modal kerja yang efektif akan meningkatkan kepercayaan investor untuk menanamkan modalnya sehingga berpengaruh terhadap nilai perusahaan. Hasil penelitian Randhy (2017) menemukan bahwa secara parsial perputaran modal kerja berpengaruh positif dan signifikan terhadap nilai perusahaan, namun sebaliknya penelitian Christiana dan Sintje (2016) menemukan bahwa perputaran modal kerja tidak memiliki pengaruh terhadap nilai perusahaan.

Ukuran perusahaan (size) juga merupakan suatu indikator dari kekuatan finansial suatu perusahaan. Perusahaan besar lebih memiliki kepercayaan investor dibandingkan dengan perusahaan kecil karena perusahaan besar dianggap memiliki kondisi yang stabil. Sebuah perusahaan yang besar tentu mampu mempertahankan keberadaannya dengan baik dan memiliki akses yang mudah di dalam pasar modal bila dibandingkan dengan perusahaan yang kecil (Robinhot, 2013). Menurut Mafira Haidar (2019) perusahaan besar akan memiliki kapitalisasi pasar yang besar, nilai buku yang besar dan laba yang tinggi. Perusahaan besar memiliki kontrol yang lebih baik (greater control) terhadap kondisi pasar, sehingga mereka mampu menghadapi persaingan ekonomi, yang membuat mereka menjadi kurang rentan terhadap fluktuasi ekonomi (Laily, 2018). Semakin besar ukuran perusahaan maka semakin mudah perusahaan mendapatkan aliran dana baik berasal dari internal maupun eksternal yang dapat digunakan untuk memperluas usahanya. Semakin banyak sumber dana yang didapatkan, tentu operasional perusahaan akan berjalan secara maksimum, hal tersebut tentu akan meningkatkan harga saham dari perusahaan, dengan meningkatnya harga saham perusahaan menandakan adanya peningkatan nilai perusahaan. Hasil penelitian (Lestari, 2016) menunjukkan bahwa ukuran perusahaan mempunyai pengaruh positif dan signifikan terhadap nilai perusahaan, sedangkan hasil penelitian S Handayani (2013) menunjukkan bahwa secara parsial ukuran perusahaan berpengaruh negatif terhadap nilai perusahaan.

Rasio profitabilitas mengukur tingkat keberhasilan perusahaan dalam menghasilkan laba dan menunjukkan tingkat pengembalian yang akan diperoleh pemegang saham atas investasi pada perusahaan. Return On Equity (ROE) membandingkan besarnya laba bersih terhadap ekuitas saham biasa. Oleh sebab itu, ROE dianggap sebagai representasi dari kekayaan pemegang saham atau nilai perusahaan (Hanafi dan Halim, 2016). Hasil penelitian Laily (2018) dan Randhy (2017) menyatakan bahwa profitabilitas mempunyai pengaruh positif dan signifikan terhadap nilai perusahaan, Menurut Christiana dan Sintje 
(2016) profitabilitas tidak berpengaruh terhadap nilai perusahaan. Sedangkan Abdurrahman dan Sri (2014) menyatakan bahwa profitabilitas berpengaruh terhadap harga saham.

Industri makanan dan minuman dipilih sebagai objek penelitian karena karakteristik kunci perusahaan, dimana memiliki prospek yang bagus kebutuhan makanan dan minuman bagi konsumen tidak akan ada matinya, sehingga diharapkan perusahaan jenis ini akan going concern dalam jangka panjang. Hasilhasil riset sebelumnya yang tidak konsisten serta pengujian atas manfaat informasi akuntansi suatu perusahaan sebagai bahan pertimbangan bagi para investor untuk berinvestasi pada perusahaan menjadi motivasi yang mendorong peneliti untuk melanjutkan riset-riset sebelumnya. Adapun tujuan penelitian ini adalah menganalisis pengaruh leverage, perputaran modal kerja, ukuran perusahaan dan profitabilitas terhadap nilai perusahaan baik secara simultan maupun parsial.

\section{Tinjauan Pustaka dan Pengembangan Hipotesis \\ Teori Relevansi Nilai (Value Relevance Theory)}

Penelitian mengenai relevansi nilai muncul karena adanya kebutuhan para investor untuk mengetahui nilai suatu perusahaan. Laporan keuangan berperan besar bagi para investor dalam penilaian perusahaan. Hal ini karena laporan keuangan memuat informasi yang dapat diandalkan mengenai kejadiankejadian atau transaksi bisnis perusahaan selama satu periode. Laba merupakan informasi dalam laporan keuangan yang paling sering dipakai oleh para investor dalam penilaian perusahaan. Pencapaian laba yang besar mengindikasisan bahwa perusahaan mempunyai prestasi yang baik sehingga dapat meningkatkan nilai perusahaan di mata para investor. Ketika informasi laba dapat dipakai sebagai pengukur dalam menangkap atau merangkum seluruh peristiwa ekonomi yang berdampak pada harga saham atau nilai perusahaan, maka laba tersebut dipandang memiliki relevansi nilai (Zacharias and Wirama, 2015).

Sebuah informasi akuntansi dikatakan memiliki nilai relevansi jika 1) informasi laporan keuangan mengandung nilai intrinsik sehingga berpengaruh pada harga saham, 2) informasi laporan keuangan merupakan nilai yang relevan bila mengandung variabel yang dapat digunakan dalam model penelitian atau memprediksi variabel-variabel tersebut, 3) hubungan statistik digunakan untuk mengukur apakah investor benar-benar menggunakan informasi tersebut dalam penetapan harga, sehingga nilai relevan diukur dengan kemampuan informasi laporan keuangan untuk mengubah harga saham karena menyebabkan investor memperbaiki ekspektasinya, 4) relevansi nilai diukur dengan kemampuan informasi laporan keuangan untuk menangkap berbagai macam informasi yang mempengaruhi nilai saham (Seviana, 2018) [30].

\section{Teori Sinyal (Signalling Theory)}

Teori sinyal (signaling theory) menjelaskan bahwa informasi yang dikeluarkan perusahaan sangat penting karena mempengaruhi keputusan investasi dari pihak luar perusahaan. Sinyal yang dikeluarkan oleh perusahaan biasanya suatu informasi tentang kinerja pihak manajemen perusahaan agar keinginan pemilik dapat direalisasikan. Laporan tahunan bisa menjadi sumber informasi yang dikeluarkan oleh perusahaan dan bisa sebagai pemberi sinyal kepada investor, informasi pada laporan tahunan biasanya berisi kondisi keuangan maupun non-keuangan perusahaan (Darmayanti, 2016)[31].

Informasi merupakan salah satu unsur yang penting bagi para pemegang saham dan juga pelaku bisnis karena hakekat informasi berguna untuk memberikan atau menyajikan penjelasan dan gambaran untuk keadaan saat ini maupun keadaan masa yang akan datang guna mempertahankan kelangsungan hidup suatu perusahaan. Informasi digunakan sebagai alat untuk mengambil keputusan investasi di pasar modal sehingga informasi yang disajikan harus lengkap, akurat, relevan dan tepat waktu. Menurut (Jogiyanto, 2016)[32] informasi dipublikasikan sebagai suatu pengumuman akan memberikan sinyal bagi investor dalam pengambilan keputusan investasi. Jika pengumuman tersebut mengandung nilai positif, maka diharapkan pasar akan bereaksi pada waktu pengumuman tersebut diterima oleh pasar. Pada waktu informasi diumumkan dan semua pelaku pasar sudah menerima 
informasi tersebut, pelaku pasar terlebih dahulu menginterpretasikan dan menganalisis informasi tersebut sebagai sinyal baik (good news) atau sinyal buruk (bad news). Salah satu jenis informasi yang dikeluarkan oleh perusahaan yang dapat menjadi sinyal bagi pihak diluar perusahaan terutama bagi investor adalah laporan tahunan. Informasi yang diungkapkan dalam laporan tahunan dapat berupa informasi akuntansi yaitu informasi yang berkaitan dengan laporan keuangan dan informasi non akuntansi yaitu informasi yang tidak berkaitan dengan laporan keuangan.

\section{Nilai Perusahaan (Value of the Firm)}

Menurut (Andriyani, 2017)[33] nilai perusahaan didefinisikan sebagai persepsi pasar yang berasal dari investor, kreditor dan stakeholder lain terhadap kondisi perusahaan yang tercermin pada nilai pasar saham perusahaan yang bisa menjadi ukuran nilai perusahaan. Nilai perusahaan dapat dipengaruhi oleh harga saham perusahaan tersebut dipasar modal, apabila harga saham suatu perusahaan dipasar modal dalam keadaan stabil dan terus mengalami kenaikan dalam jangka panjang dapat diartikan bahwa perusahaan tersebut mengalami pertumbuhan terus-menerus. Nilai perusahaan juga merupakan konsep penting bagi investor, karena merupakan indikator bagi pasar untuk menilai perusahaan secara keseluruhan yang tercermin dalam harga saham. Nilai perusahaan yang tinggi dapat meningkatkan kemakmuran bagi para pemegang saham, sehingga para pemegang saham akan menginvestasikan modalnya kepada perusahaan tersebut (Ikhsan, 2019)[34].

Rasio Tobin's Q merupakan penilaian estimasi pasar keuangan saat ini tentang nilai hasil pengembalian dari setiap dolar investasi. Tobin's $Q$ adalah nilai pasar dari aset perusahaan dengan biaya penggantinya. Menurut konsepnya, rasio $\mathrm{Q}$ lebih unggul daripada rasio nilai pasar terhadap nilai buku karena rasio ini fokus pada berapa nilai perusahaan saat ini secara relatif terhadap berapa biaya yang dibutuhkan untuk menggantinya saat ini. Dalam praktiknya, rasio Q sulit untuk dihitung dengan akurat karena memperkirakan biaya penggantian atas aset sebuah perusahaan bukanlah suatu pekerjaan yang mudah (Margaretha, 2014)[35]. Rumus untuk menghitung Tobin's $Q$ Ratio:

$$
\text { Tobin's } Q=\frac{E M V+D}{E B V+D}
$$

dimana :

$$
\begin{array}{ll}
\mathrm{Q} & =\text { Nilai Perusahaan } \\
\mathrm{EMV} & =\text { Nilai Pasar Ekuitas (Equity Market Value) } \\
\mathrm{EBV} & =\text { Nilai Buku dari Ekuitas (Equity Book Value) } \\
\mathrm{D} & =\text { Nilai buku dari Total Hutang. }
\end{array}
$$

\section{Rasio Leverage}

Rasio solvabilitas atau leverage ratio merupakan rasio yang digunakan untuk mengukur sejauh mana aktiva perusahaan dibiayai oleh utang. Dalam arti luas rasio solvabilitas atau leverage digunakan untuk mengukur kemampuan perusahaan untuk membayar seluruh kewajibannya, baik jangka pendek maupun jangka panjang apabila perusahaan dibubarkan. Oleh karena itu, manajer keuangan dituntut untuk mengelola rasio solvabilitas dengan baik sehingga mampu menyeimbangkan pengembalian yang tinggi dengan tingkat rasio yang dihadapi (Kasmir, 2016) [36].

Rasio leverage merupakan proporsi total hutang terhadap rata-rata ekuitas pemegang saham. Rasio tersebut digunakan untuk mengukur seberapa jauh perusahaan dibiayai oleh dana pinjaman (Wiagustini, 2014) [37]. Rasio Hutang Terhadap Aktiva (Debt to Asset Ratio) digunakan untuk mengukur seberapa besar aktiva dibiayai oleh utang, baik jangka pendek ataupun jangka panjang. Semakin rendah rasio ini artinya semakin baik bagi keuangan perusahaan, sebab keamanan dananya semakin baik . Rumus untuk menghitung Debt to Assets Ratio adalah :

$$
D A R=\frac{\text { Total Hutang }}{\text { Total Aktiva }} \times 100 \%
$$

\section{Perputaran Modal Kerja}

Perputaran modal kerja atau working capital turnover adalah suatu rasio yang digunakan mengukur keefektifan modal kerja perusahaan selama periode tertentu (Clairene E.E (2013:1583) dalam Randhy, 2017)[38]. Untuk mengukur rasio ini kita membandingkan penjualan bersih dengan modal kerja atau dengan modal kerja rata-rata. Dari hasil perhitungan apabila perputaran modal kerja rendah berarti pengolalaan modal kerja belum 
efektif dan sebaliknya apabila perputaran modal tinggi berarti modal kerja perusahaan efektif. Rasio Perputaran Modal Kerja dihitung dengan rumus:

$$
\text { Perput Mdl Krj }=\frac{\text { Penjualan Bersih }}{\text { Aset Lancar }- \text { Utang Lancar }}
$$

\section{Ukuran Perusahaan}

Ukuran perusahaan adalah suatu skala dimana dapat diklasifikasikan besar kecilnya suatu perusahaan menurut berbagai cara antara lain total aset, nilai pasar saham, dan lain lain. Pada dasarnya, ukuran perusahaan terbagi dalam 3 kategori yaitu perusahaan besar (large firm), perusahaan menengah (medium firm), dan perusahaan kecil (small firm). Dalam berinvestasi di pasar modal, ratarata investor akan melihat ukuran dari suatu perusahaan dengan nilai kapitalisasi pasar, yaitu nilai pasar dari saham yang diterbitkan. Kapitalisasi pasar didapatkan dari mengalikan jumlah saham perusahaan yang beredar dengan harga saham penutupan, besar atau kecilnya perusahaan dapat dilihat dari kapitalisasi pasarnya ( Yoedy, 2013)[39]. Dengan semakin besarnya nilai kapitalisasi pasar akan menunjukkan bahwa ukuran perusaahaan juga semakin besar. Perhitungan kapitalisasi pasar (MCaP) menurut (Pakarti, 2008)[40] dapat menggunakan rumus close price tahun ke $\mathrm{t}$ dikalikan jumlah saham beredar. Untuk meminimalkan kemungkinan terjadinya heterokedasititas karena kapitalisasi pasar dalam satuan mata uang yang jumlahnya jutaan atau lebih, maka kapitalisasi pasar harus dilakukan logaritma natural (Gujarati, 2014)[41]

\section{LN_MCaP}

dimana:

LN_McaP $=$ Logaritma Natural Kapitalisasi Pasar

Profitabilitas

Rasio Return On Equity

(ROE) digunakan untuk mengukur kemampuan perusahaan terhadap penghasilan yang dicapai bagi pemilik perusahaan atas modal yang diinvestasikan kepada perusahaan. Semakin tinggi nilai ROE maka akan semakin tinggi pula penghasilan yang akan diterima oleh pemilik perusahaan. Rumus untuk menghitung Return On Equity (ROE) adalah :

$$
\begin{aligned}
& \text { ROE } \\
& =\frac{\text { Laba Bersih Sebelum Pajak }}{\text { Total Ekuitas }} \times 100 \%
\end{aligned}
$$

\section{Pengembangan Hipotesis}

\section{Pengaruh Leverage, Perputaran Modal Kerja, Ukuran Perusahaan, dan Profitabilitas Secara Simultan Terhadap Nilai Perusahaan}

Rasio Leverage yang diproksikan dengan Debt to Equity Ratio (DER) menunjukkan besarnya total utang terhadap total ekuitas. Semakin besar utang menunjukkan semakin besar ketergantungan perusahaan terhadap pihak luar sehingga risiko perusahaan semakin besar. Risiko dalam memenuhi seluruh kewajibannya akan mempengaruhi kinerja perusahaan sehingga akan mempengaruhi kepercayaan investor terhadap perusahaan dan selanjutnya akan mempengaruhi nilai perusahaan (Wirajaya, 2013)[42]. Perputaran modal kerja (Working Capital Turnover) menunjukkan banyaknya penjualan dalam rupiah yang dapat diperoleh perusahaan untuk setiap rupiah modal kerja. Perputaran modal kerja yang baik maka akan mendukung kegiatan operasional perusahaan pun akan berjalan dengan baik, secara tidak langsung membawa perusahaan kedalam kondisi yang menguntungkan. Semakin cepat modal kerjanya, berarti laba yang diperoleh semakin besar, laba yang tinggi akan mempengaruhi nilai perusahaan (Ishaq and Asyik, 2015)[43]. Ukuran perusahaan yang meningkat menunjukkan bahwa perusahaan terus mengalami perkembangan usaha sehingga menghasilkan laba yang tinggi. Pada perusahaan yang berukuran besar, manajer akan berusaha memaksimalkan kemampuannya mengelola perusahaan untuk meningkatkan nilai perusahaan, karena pada perusahaan besar cenderung menjadi sorotan masyarakat (Farid dan Amboningtyas, 2015)[44]. Profitabilitas memberikan indikasi prospek perusahaan yang baik sehingga dapat memicu investor untuk ikut meningkatkan permintaan saham. Permintaan saham yang meningkat akan menyebabkan nilai perusahaan meningkat juga. Perusahaan yang memiliki profitabilitas yang cukup tinggi akan meningkatkan kepercayaan investor sehingga mendapatkan dana yang cukup, dan selanjutnya perusahaan dapat meningkatkan kinerjanya yang berakibat pada meningkatnya nilai perusahaan (Laily, 
2018)[45]. Sehingga dapat disimpulkan bahwa secara simultan Leverage, Perputaran Modal Kerja, Ukuran perusahaan, dan Profitabilitas berpengaruh terhadap Nilai Perusahaan. Maka dapat dikembangkan hipotesis sebagai berikut:

$\mathrm{H} 1$ : Leverage, perputaran modal kerja, ukuran perusahaan, dan profitabilitas secara simultan berpengaruh terhadap nilai perusahaan.

\section{Pengaruh Leverage secara parsial terhadap nilai perusahaan}

Suatu perusahaan tentu membutuhkan sumber pendanaan untuk dapat menjalankan aktivitas perusahaan. Sumber pendanaan tersebut dapat berasal dari modal sendiri atau berasal dari sumber yang lain misalnya dari pinjaman atau hutang. Pengelolaan leverage sangatlah penting, sebab keputusan dalam penggunaan hutang yang tinggi dapat meningkatkan nilai perusahaan yang dikarenakan adanya pengurangan atas pajak penghasilan (Mustanda, 2017)[46]. Hutang yang tinggi juga dapat menyebabkan resiko yang besar terhadap pengembalian atas investasi yang mereka tanamkan karena hutang akan menciptakan beban tetap berupa bunga yang harus dibayarkan oleh perusahaan sehingga laba menjadi menurun dan modal pemegang saham juga ikut menurun (Sari, 2016)[47]. Maka dapat dikembangkan hipotesis sebagai berikut :

$\mathrm{H} 2$ : Leverage secara parsial berpengaruh negatif terhadap nilai perusahaan.

\section{Pengaruh Perputaran Modal Kerja secara parsial terhadap nilai perusahaan}

Menurut (Randhy, 2017)[48] perputaran modal kerja menunjukan jumlah rupiah penjualan netto yang diperoleh bagi setiap rupiah modal kerja. Semakin erat perputaran masing-masing komponen modal kerja perusahaan dan semakin banyak dana yang dapat diinvestasikan kembali ke dalam modal kerja dapat meningkatkan profitabilitas perusahaan, Meningkatnya efektifitas perputaran modal kerja ini tentu akan meningkatkan nilai perusahaan karena minat para investor untuk menanamkan modalnya meningkat. Maka dapat dikembangkan hipotesis sebagai berikut :
H3 : Perputaran modal kerja secara parsial berpengaruh positif terhadap nilai perusahaan.

\section{Pengaruh Ukuran Perusahaan secara parsial terhadap nilai perusahaan}

Ukuran perusahaan adalah peningkatan dari kenyataan bahwa perusahaan besar akan memiliki kapitalisasi pasar yang besar, nilai buku yang besar dan laba yang tinggi. Perusahaan besar memiliki kontrol yang lebih baik terhadap kondisi pasar, sehingga mereka mampu menghadapi persaingan ekonomi (Mafira, 2019)[49]. Ukuran perusahaan dapat menunjukan prestasi dari suatu perusahaan, dimana perusahaan yang memiliki ukuran yang besar dianggap mampu mengelola perusahaan yang baik dan memiliki kinerja yang baik pula, sehingga perusahaan akan lebih mudah menarik investor. Perusahaan yang memiliki ukuran yang besar dengan kinerja yang baik dalam menanamkan modalnya, akan meningkatkan harga saham yang berpengaruh pada meningkatnya nilai perusahaan (Dwi dan Dahlia, 2015)[50]. Maka dapat dikembangkan hipotesis sebagai berikut :

H4 :Ukuran perusahaan secara parsial berpengaruh positif terhadap nilai perusahaan.

\section{Pengaruh Profitabilitas secara parsial terhadap nilai perusahaan}

Profitabilitas merupakan laba yang dihasilkan perusahaan berdasarkan ukuran dari kinerja perusahaan. Profitabilitas yang meningkat mencerminkan peningkatan efisiensi perusahaan, sehingga kinerja perusahaan semakin membaik. Perusahaan dengan kinerja yang baik dilihat melalui perolehan labanya akan meningkatkan kepercayaan investor yang menginginkan return dari investasi yang dilakukan. Calon investor selalu mencari perusahaan dengan kinerja baik kemudian akan melakukan kegiatan investasi pada perusahaan, sehingga kegiatan tersebut dapat meningkatkan persepsi pasar dan nilai perusahaan akan meningkat (Mustanda, 2017)[51]. Profitabilitas perusahaan yang terus meningkat akan semakin dapat meningkatkan tingkat kepercayaan dan minat para calon investor untuk menanamkan investasinya pada perusahaan tersebut (Ramdhonah dkk, 
2019)[52]. Maka dapat dikembangkan hipotesis sebagai berikut :

H5 : Profitabilitas secara parsial berpengaruh positif terhadap nilai perusahaan.

\section{Metode Penelitian \\ Desain Penelitian}

Desain penelitian yang digunakan dalam penelitian ini adalah kausalitas yaitu penelitian yang bertujuan untuk mencari pengaruh atau hubungan sebab akibat. Penelitian ini bertujuan untuk menguji pengaruh variabel independen yaitu leverage, perputaran modal kerja, ukuran perusahaan, dan profitabilitas terhadap variabel dependen yaitu nilai perusahaan. Adapun model penelitian ini adalah sebagai berikut :

Gambar 1. Model Penelitian

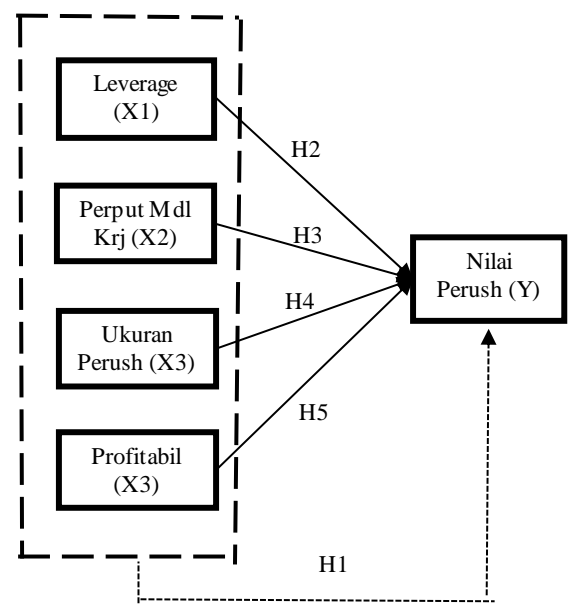

\section{Populasi, Sampel dan Teknik Pengambilan Sampel}

Populasi dalam penelitian ini adalah perusahaan yang bergerak dalam industri makanan dan minuman yang terdaftar di Bursa Efek Indonesia pada periode 2015 sampai dengan 2019 berjumlah 80 perusahaan. Teknik pengambilan sampel dalam penelitian ini menggunakan metode purposive sampling, dengan kriteria perusahaan yang secara konsisten terdaftar di bursa efek selama tahun penelitian. Jumlah sampel dalam penelitian ini adalah 70 data.

\section{Definisi Operasional Variabel}

Pada Penelitian ini melibatkan 5 variabel yang terdiri atas 1 variabel terikat (variabel dependen) dan 4 variabel bebas (variabel independen). Variabel bebas tersebut adalah leverage, perputaran modal kerja, ukuran perusahaan, dan profitabilitas. Variabel terikatnya adalah nilai perusahaan. Berikut ini adalah variabel-variabel dalam penelitian ini adalah:

a. Variabel Dependen (Y)

Variabel dependen dalam penelitian ini adalah Nilai Perusahaan. Proksi Nilai Perusahaan dalam penelitian ini diproksikan dengan Tobin's $Q$, Rasio Tobin's $Q$ adalah suatu rasio yang digunakan untuk menentukan nilai perusahaan dan mengambil keputusan investasi dengan cara membandingkan harga pasar perusahaan dengan nilai buku ekuitas .

b. Variabel Independen (X)

Variabel independen terdiri dari :

1) Leverage $\left(X_{1}\right)$

Leverage merupakan rasio yang menunjukkan bagaimana kemampuan perusahaan dalam melunasi kewajibannya.

Dalam penelitian ini leverage diproksikan dengan Debt to Equity Ratio (DER). DER merupakan rasio yang digunakan untuk menilai utang dengan ekuitas.

2) Perputaran Modal Kerja $\left(X_{2}\right)$

Perputaran modal kerja atau working capital turnover adalah suatu rasio yang digunakan mengukur berapa banyak modal kerja berputar selama suatu periode tertentu.

3) Ukuran Perusahaan $\left(X_{3}\right)$

Ukuran perusahaan (Firm Size) pada penelitian ini diukur dengan formulasi nilai pasar (market value).

4) Profitabilitas $\left(X_{4}\right)$

Profitabilitass dalam penelitian ini menggunakan proksi Return On Equity (ROE). ROE ini sering disebut dengan rate of return on Net Worth yaitu kemampuan perusahaan dalam menghasilkan keuntungan dengan modal sendiri yang dimiliki.

Berikut ini adalah definisi operasonal variabel : Tabel 1 Definisi Operasional Variabel

\begin{tabular}{|c|c|c|c|}
\hline & Variabel & Proksi & Skala \\
\hline$X_{1}$ & Leverage & $\begin{array}{l}\text { DER } \\
=\frac{\text { Total Hutang }(\text { Debt })}{\text { Total Ekuitas }(\text { Equity })} \times 100 \%\end{array}$ & Rasio \\
\hline $\mathrm{X}_{2}$ & $\begin{array}{c}\text { Perputaran } \\
\text { Modal Kerja }\end{array}$ & Penjualan Bersih & Rasio \\
\hline$X_{3}$ & $\begin{array}{c}\text { Ukuran } \\
\text { Perusahaan }\end{array}$ & $\begin{array}{c}\text { Aset Lancar -Utang Lancar } \\
\text { Firm Size = Ln(Nilai Kapitalisasi } \\
\text { Pasar) }\end{array}$ & Rasio \\
\hline
\end{tabular}




\begin{tabular}{cccc}
\hline & Variabel & Proksi & Skala \\
\hline $\mathrm{X}_{4}$ & Profitabilitas & ROE & Rasio \\
& $=\frac{\text { Earning After Tax }}{\text { Total Ekuitas }} \times 100 \%$ & \\
$\mathrm{Y}$ & $\begin{array}{c}\text { Nilai } \\
\text { Perusahaan }\end{array}$ & Tobin's $Q=\frac{(E M V+D)}{(E B V+D)}$ & Rasio
\end{tabular}

\section{Teknik Analisis Data}

Teknik analisis yang digunakan dalam penelitian ini adalah teknik analisis regresi linier berganda atau multiple linier regresion untuk memperoleh gambaran yang menyeluruh mengenai hubungan antara variabel yang satu dengan yang lain. Adapun model persamaan regresi dalam penelitian ini dapat dirumuskan sebagai berikut .

$$
Y=a+\beta 1 X_{1}+\beta 2 X_{2}+\beta 3 X_{3}+\beta 4 X_{4}+e
$$

Dimana :

$Y=$ Nilai Perusahaan

$\mathrm{a}=$ Konstanta

$\beta 1, \beta 2, \beta 3, \beta 4=$ Koefisien regresi

$\mathrm{X}_{1}=$ leverage (Dept to Equity Ratio)

$\mathrm{X}_{2}=$ Perputaran Modal Kerja

$\mathrm{X}_{3}=$ Profitabilitas (Return On Equity)

$\mathrm{X}_{4}=$ Ukuran Perusahaan

$\mathrm{e}=$ error term

\section{Uji Statistik Deskriptif}

Statistik deskriptif digunakan untuk mendeskripsikan variabel-variabel penelitian yang diamati yaitu Leverage, Perputaran Modal Kerja, Ukuran Perusahaan, dan Profitabilitas dan nilai perusahaan dengan menggunakan rata-rata (mean).

\section{Uji Asumsi Klasik}

\section{a. Uji Normalitas}

Uji normalitas data pada penelitian ini menggunakan uji kolmogorov-smirnov test. Dasar pengambilan keputusan adalah :

- Jika Signifikansi > 0,05 maka data terdistribusi normal

- Jika Signifikansi < 0,05 maka data tidak terdistibusi secara normal

\section{b. Uji Multikolinieritas}

Menurut (Ghazali, 2016) [56] Uji multikolonieritas bertujuan untuk menguji apakah model regresi ditemukan adanya kolerasi antara variabel bebas (independent). Untuk mendeteksi ada atau tidaknya multikolonieritas di dalam model regresi adalah dapat dilihat dari nilai tolerance dan variante inflation factor
(VIF), jika nilai tolerance $\geq 0,10$ dan nilai VIF $\leq 10 / 10,00$ menunjukan bahwa tidak ada multikolinearitas pada antar variabel independent.

\section{c. Uji Autokolerasi}

Uji autokolerasi bertujuan untuk menguji apakah dalam model regresi linear ada kolerasi antara kesalahan pengganggu pada periode $t$ dengan kesalahan pengganggu pada periode $\mathrm{t}-1$. Untuk mendeteksi ada tidaknya gejala autokorelasi dalam model regresi bisa dilakukan dengan pendeteksian dengan percobaan Durbin Watson (Uji DW) dengan ketentuan jika angka DW diantara $\mathrm{du}<\mathrm{dw}<4$-du, berarti tidak ada autokorelasi.

\section{d. Uji Heteroskedastisitas}

Model regresi yang baik adalah tidak terjadi heterokedastisitas. Untuk dapat mendeteksi ada atau tidaknya heteroskedastisitas dapat dilihat dari grafik plot antara nilai prediksi variabel terikat (dependen). Jika tidak ada pola yang jelas, serta titik-titik menyebar di atas dan di bawah angka 0 pada sumbu Y, maka tidak terjadi heteroskedastisitas

\section{Uji Hipotesis}

\section{a. Uji Simultan (Uji Statistik F)}

Uji F digunakan untuk menguji pengaruh variabel independen terhadap variabel dependen secara simultan. Adapun kriteria pengambilan keutusan untuk uji simultan adalah sebagai berikut :

1) Jika sig < 0.05, maka Ha diterima dan Ho ditolak, artinya variabel independen secara simultan berpengaruh positif terhadap variabel dependen.

2) Jika sig > 0.05, maka Ha ditolak dan Ho diterima, artinya variabel independen secara simultan tidak berpengaruh positif terhadap variabel dependen.

\section{b. Uji Parsial (Uji Statistik t)}

Uji $\mathrm{t}$ ini bertujuan untuk mengetahui besarnya pegaruh masing-masing variabel independen secara individual (parsial) terhadap variabel dependen. Adapun kriteria pengambilan keputusan sebagai berikut:

1) Jika sig < 0.05, maka Ha diterima dan Ho ditolak, artinya variabel independen 
berpengaruh positif terhadap variabel dependen.

2) Jika sig > 0.05, maka Ha ditolak dan Ho diterima, artinya variabel independen tidak berpengaruh positif terhadap variabel dependen.

\section{Uji Koefisien Determinan $\left(\mathbf{R}^{2}\right)$}

Pengujian ini dilakukan untuk mengetahui tingkat ketepatan yang terbaik dalam analisis regresi dalam hal ini ditunjukkan oleh besarnya koefisien determinasi. Koefisien determinasi $\left(R^{2}\right)$ pada intinya mengukur seberapa jauh kemampuan model dalam menerangkan variasi variabel dependen. Nilai yang mendekati satu berarti variabel-variabel independen memberikan hampir semua informasi yang dibutuhkan untuk memprediksi variasi variabel dependen.

\section{Hasil Penelitian Dan Pembahasan Statistik deskriptif}

Populasi dalam penelitian ini adalah seluruh perusahaan makanan dan minuman yang terdaftar di Bursa Efek Indonesia (BEI) periode 2015-2019. Sedangkan jumlah sampel dalam penelitian ini adalah 70 data.

Tabel 2

Hasil Analisis Deskriptif

\begin{tabular}{lr|} 
& \multicolumn{1}{c|}{ Mean } \\
\hline Leverage & .9148 \\
\hline Perput Modal Kerja & 9.7756 \\
\hline Ukuran Perusahaan & 29.1144 \\
\hline Profitabilitas & .2198 \\
\hline Nilai Perusahaan & 2.8190 \\
\hline
\end{tabular}

Dari tabel di atas dapat diketahui bahwa nilai rata-rata variabel leverage adalah sebesar 0,9148 dapat disimpulkan bahwa perusahaan memiliki risiko cukup tinggi karena hutang perusahaan hampir sama dengan modal yang dimiliki perusahaan. Nilai rata-rata perputaran modal kerja adalah sebesar 9.7756 yang berarti bahwa modal kerja berputar sebanyak 9.77 kali dalam jangka waktu 1 tahun yang berarti membutuhkan waktu 1,3 bulan modal dapat berputar kembali. Hal tersebut menunjukkan bahwa perputaran modal kerja pada perusahaan makanan dan minuman tergolong tinggi. Nilai rata-rata variabel ukuran perusahaan adalah sebesar 29.1144 atau
$29,1 \%$ yang artinya besarnya ukuran perusahaan pada setiap perusahaan cukup besar. Nilai rata-rata profitabilitas adalah sebesar 0.2198 , yang artinya profitabilitas pada industri ini tergolong tinggi. Nilai rata-rata nilai perusahaan yang diproksikan dengan Tobins'Q adalah sebesar 2.8190, sehingga dapat disimpulkan bahwa pada industri ini setiap 1 nilai buku ekuitas dihargai oleh pasar sebesar 2,819, hal ini menunjukkan nilai perusahaan tergolong tinggi.

\section{Uji Asumsi Klasik}

Dalam penelitian ini, uji asumsi klasik yang dilakukan meliputi uji normalitas data, uji multikolinieritas, uji autokorelasi dan uji heterokesdastisitas. Adapun hasil pengujian asumsi klasik tersebut adalah sebagai berikut :

Tabel 3

Hasil Uji Asumsi Klasik

\begin{tabular}{|c|c|c|c|c|}
\hline $\begin{array}{l}\text { Normalitas Data } \\
\text { asympsig }>0.05\end{array}$ & \multicolumn{2}{|c|}{$\begin{array}{c}\text { Multikolinieritas (VIF) } \\
\text { syarat: VIF }<10 \\
\end{array}$} & $\begin{array}{l}\text { Autokorelasi } \\
\text { du }<d w<4 \text { - du }\end{array}$ & $\begin{array}{c}\text { Heterokesdastisitas } \\
\text { syarat : titik-titik menyebar }\end{array}$ \\
\hline \multirow{4}{*}{ asymp sig $=0.070$} & Leverage & 1.111 & $d u=1.735$ & - \\
\hline & Perputaran MdI Krj & 1.075 & $d w=1.871$ & 4 \\
\hline & Ukr Perusahaan & 1.103 & $1.735<1.871<4-1.735$ & $=$ \\
\hline & Profitabilitas & 1.160 & $1.735<1.871<2.265$ & - \\
\hline
\end{tabular}

Berdasarkan tabel 3 hasil uji normalitas dengan one sample Kolmogorov-smirnov menunjukkan bahwa nilai Asymp. Sig. (2-tailed) adalah sebesar $0.070>0.05$, maka dapat disimpulkan bahwa data berdistribusi dengan normal dan dapat dilanjutkan ke tahap selanjutnya. Hasil uji multikolinieritas diatas maka diperoleh angka VIF $<10$. Sehingga dapat disimpulkan bahwa dalam penelitian ini tidak ada korelasi antar variabel independen (bebas) atau tidak terjadi multikolinieritas. Dari hasil pengolahan menunjukan angka Durbin Watson sebesar 1.871 , diantara 1.735 dan 2.265, maka dapat disimpulkan tidak terjadi autokorelasi. Hasil uji heteroskedastisitas titiktitik menyebar secara acak dan tidak membentuk pola tertentu, sehingga dapat disimpulkan tidak terjadi heteroskedastisitas. 


\section{Uji Hipotesis}

Tabel 4

Hasil Uji Hipotesis

\begin{tabular}{llrr}
\hline \multicolumn{1}{c}{ Model } & \multicolumn{1}{c}{ Variabel } & \multicolumn{1}{c}{ B } & \multicolumn{1}{c}{ Sig. } \\
\hline \multirow{4}{*}{ Uji parsial } & (Constant) & -4.540 & .053 \\
& Leverage & -.705 & .035 \\
& Perputaran Mdl Krj & -.112 & .057 \\
& Ukuran Perush & .229 & .005 \\
Uji Simultan & Profitabilitas & 6.600 & .001 \\
Uji Koef Determinasi & $\mathrm{F}$ & 9.351 & 0.000 \\
& $\mathrm{R}^{2}$ & 0.468 &
\end{tabular}

Dari hasil pengujian tabel 4 di atas, maka dapat dijelaskan pembuktian hipotesis yang telah dikembangkan pada bab sebelumnya, yaitu sebagai berikut:

1. Uji pengaruh Leverage, Perputaran Modal Kerja, Ukuran Perusahaan dan Profitabilitas secara simultan terhadap Nilai Perusahaan.

Nilai signifikansi untuk hasil pengujian $F$ (anova) adalah sebesar 0.000 lebih kecil dari 0.05, maka H1 diterima, artinya Leverage, Perputaran Modal Kerja, Ukuran Perusahaan, dan Profitabilitas secara simultan berpengaruh signifikan terhadap Nilai Perusahaan.

Leverage yang diproksikan dengan Debt to Equity Ratio (DER) menunjukkan seberapa besar modal yang dibiayai oleh hutang pada suatu perusahaan, perusahaan dengan hutang yang besar mempunyai tingkat modal yang besar pula untuk menghasilkan laba pada perusahaan. Hal tersebut menjadi dampak positif bagi perusahaan yang dapat meningkatkan kepercayaan investor terhadap perusahaan sehingga akan berdampak positif terhadap nilai perusahaan. Perputaran Modal Kerja yang diproksikan dengan Working Capital Turnover (WCT) menunjukkan seberapa besar tingkat perputaran modal pada suatu perusahaan yang dapat digunakan untuk membiayai kegiatan perusahaan. Modal kerja yang baik akan menunjang tingginya profitabilitas perusahaan, karena semakin tinggi tingkat perputaran modal kerja maka semakin efektif penggunaan modal kerja dan semakin cepat modal kerja berputar sehingga semakin besar keuntungan yang didapatkan untuk meningkatkan profitabilitas perusahaan. Ukuran Perusahaan juga dapat mempengaruhi nilai perusahaan, semakin besar ukuran perusahaan maka kesempatan perusahaan untuk memperoleh sumber dana dari pasar modal jauh lebih besar, hal tersebut tentu akan berdampak positif bagi perusahaan karena dengan modal yang besar tentu laba yang dihasilkan juga jauh lebih besar. Profitabilitas yang tinggi juga akan mempengaruhi nilai perusahaan karena dengan profitabilitas yang semakin tinggi maka akan berdampak pada harga saham perusahaan, hal ini dapat menjadi pertimbangan investor dalam mengambil keputusan untuk menanamkan modalnya pada perusahaan tersebut.

Leverage, Perputaran Modal Kerja, Ukuran Perusahaan, dan Profitabilitas merupakan beberapa faktor yang meningkatkan Nilai Perusahaan. Keempat faktor tersebut dapat menyebabkan investor memberikan respon positif sehingga meningkatkan nilai perusahaan. Penelitian ini didukung dengan penelitian yang dilakukan oleh Randhy (2017)] yang menyatakan bahwa Profitabilitas, Perputaran Modal Kerja, dan Struktur Modal secara simultan berpengaruh positif terhadap nilai perusahaan, serta Handayani (2013)[54] yang menyatakan bahwa karakteristik perusahaan berpengaruh secara simultan terhadap nilai perusahaan.

2. Uji pengaruh Leverage secara parsial terhadap nilai perusahaan

Hasil uji t pada variabel Leverage sebesar 1.480 dengan tingkat signifikansi 0,148> 0,05 maka $\mathrm{H} 2$ ditolak. Hal ini membuktikan bahwa Leverage tidak berpengaruh terhadap Nilai Perusahaan.

Hasil penelitian ini mengindikasikan bahwa leverage tidak berpengaruh terhadap nilai perusahaan. Besarnya utang dalam industri ini tidak menjadi bahan pertimbangan bagi para investor karena ada kemungkinan para investor justru lebih melihat pada pemanfaatan hutang sebagai modal perusahaan. Sepanjang utang digunakan untuk kegiatan operasional yang menguntungkan, maka investor tidak akan memandang bahwa besarnya utang akan meningkatkan risiko, sehingga utang tidak akan mempengaruhi nilai perusahaan. Penelitian mendukung penelitian yang dilakukan oleh (Nugroho, Abdani,2017) dan Dwi dan Dahlia (2015) yang menyatakan bahwa Leverage tidak berpengaruh terhadap nilai perusahaan. Namun pernyataan 
tersebut tidak sejalan dengan penelitian yang dilakukan oleh Suwardika dan Mustanda (2017) yang menyatakan bahwa leverage secara parsial berpengaruh terhadap nilai perusahaan.

3. Uji Pengaruh Perputaran Modal Kerja secara parsial terhadap Nilai Perusahaan

Hasil uji t pada variabel Perputaran Modal Kerja sebesar -1.314 dengan signifikansi 0,198 > 0,05 maka H3 ditolak. Hal ini membuktikan bahwa Perputaran Modal Kerja tidak berpengaruh terhadap Nilai Perusahaan.

Modal kerja yang baik akan menunjang tingginya profitabilitas perusahaan, karena semakin tinggi tingkat perputaran modal kerja maka semakin efektif penggunaan modal kerja dan semakin cepat modal kerja berputar sehingga semakin besar keuntungan yang didapatkan untuk meningkatkan profitabilitas perusahaan. Perputaran modal kerja tidak menjadi bahan pertimbangan investor dalam pengambilan keputusan investasi mungkin disebabkan karena banyak investor yang tidak mempertimbangkan aktifitas perusahaan dalam menanamkan modalnya pada perusahaan manufaktur karena investor lebih cenderung memilih perusahaan dengan aktivitas investasi jangka panjang mengingat bahwa sektor manufaktur memberikan multiplier effect yang besar karena rentan akan kondisi ekonomi yang kurang mendukung. Penelitian ini didukung dengan penelitian yang dilakukan oleh (Aprelliya dkk,2019)[58] yang menyatakan bahwa perputaran modal kerja secara parsial tidak berpengaruh terhadap nilai perusahaan. Tetapi penelitian ini tidak sejalan dengan penelitian yang dilakukan oleh Randhy Agusentoso (2017) yang menyatakan bahwa perputaran modal kerja berpengaruh positif terhadap nilai perusahaan. Karena semakin optimalnya perputaran modal sebuah perusahaan, maka modal kerja perusahaan semakin efektif dan begitu pula sebaliknya sehingga mempengaruhi dari nilai perusahaan.

4. Uji Pengaruh Ukuran Perusahaan secara parsial terhadap Nilai Perusahaan

Hasil uji $t$ pada variabel Ukuran Perusahaan sebesar 3.221 dengan tingkat signifikansi sebesar 0,003 $<0,05$ maha $\mathrm{H} 4$ diterima. Hal ini membuktikan bahwa Ukuran Perusahaan berpengaruh positif terhadap Nilai Perusahaan. Maka, semakin besar ukuran perusahaan, akan mengakibatkan peningkatan nilai perusahaan.

Ukuran perusahaan dipercaya dalam memberikan tingkat pengembalian yang tinggi kepada investor, karena perusahaan besar memiliki risiko yang lebih rendah daripada perusahaan kecil dikarenakan perusahaan besar memiliki kontrol yang lebih baik sehingga mereka mampu menghadapi persaingan ekonomi. Penelitian sebelumnya yang mendukung untuk membangun hipotesis keempat dalam penelitian ini yaitu Ikhsan (2019) dan Dwi dan Dahlia (2015) yang menyatakan bahwa Ukuran perusahaan secara parsial berpengaruh terhadap nilai perusahaan. Hasil ini tidak sesuai dengan penelitian yang dilakukan oleh Suwardika dan Mustanda (2017) yang menyatakan bahwa ukuran perusahaan secara parsial tidak berpengaruh terhadap nilai perusahaan.

5. Uji Pengaruh Profitabilitas secara parsial terhadap Nilai Perusahaan

Hasil uji t pada variabel Profitabilitas sebesar 3.700 dengan tingkat signifikansi sebesar $0,001<0,05$ maka H5 diterima. Hal ini membuktikan bahwa Profitabilitas berpengaruh positif terhadap Nilai Perusahaan.

Profitabilitas menunjukkan berapa besar perusahaan dapat menghasilkan laba yang dapat dibagikan kepada seluruh pemegang saham. Investor cenderung memilih perusahaan yang mampu menghasilkan laba yang tinggi karena dengan laba yang tinggi tentu berdampak pada pembagian dividen tinggi. Sehingga dapat disimpulkan semakin tinggi profitabilitas, maka nilai perusahaan meningkat. Hal ini sejalan dengan penelitian yang dilakukan oleh Randhy (2017), dan Handayani (2014) yang menyatakan bahwa variabel profitabilitas berpengaruh dengan variabel Nilai Perusahaan. Tetapi hasil ini tidak sejalan dengan penelitian yang dilakukan oleh Grandy dkk (2016) yang menyatakan bahwa Profitabilitas secara parsial tidak berpengaruh terhadap nilai perusahaan 


\subsection{Analisis Persamaan Regresi Linier Berganda}

Adapun uji persamaan linier dalam penelitian ini sebagai berikut :

$$
\begin{gathered}
Y=-4.259-0,582(\text { Lev })-0.081 \text { (Perput Mdl } \\
\text { Krj) }+0.362 \text { (Ukuran Perush) }+6.871 \text { (Profit) }+ \\
\text { e }
\end{gathered}
$$

Dari persamaan diatas, maka didapat penjelasan bahwa nilai konstanta sebesar 4.259 diartikan bahwa jika Leverage, Perputaran Modal Kerja, Ukuran Perusahaan, dan Profitabilitas sebesar nol, maka Nilai Perusahaan akan sebesar -4.259. Koefisien regresi $\beta 1$ Leverage sebesar $-0,582$, berarti setiap kenaikan Debt to Equity Ratio sebesar 1 satuan maka nilai perusahaan akan mengalami penurunan sebesar 0,582. Koefisien regresi $\beta 2$ Perputaran Modal Kerja sebesar -0,081, berarti bahwa setiap kenaikan Perputaran Modal Kerja sebesar 1 satuan maka nilai perusahaan akan mengalami penurunan sebesar 0,081. Koefisien regresi $\beta 3$ Ukuran Perusahaan sebesar 0,362, berarti bahwa setiap kenaikan nilai sebesar 1 satuan maka nilai perusahaan akan mengalami kenaikan sebesar 0,362. Koefisien regresi $\beta 4$ Profitabilitas sebesar 6,871, berarti bahwa setiap kenaikan Profitabilitas sebesar 1 satuan maka nilai perusahaan akan mengalami kenaikan sebesar 6,871.

\section{Uji Koefisien Determinasi (Adjusted $\mathbf{R}^{\mathbf{2}}$ )}

Hasil uji koefisien determinasi menunjukkan nilai Adjusted $\mathrm{R}^{2}$ sebesar 0.468 . Hal ini berarti bahwa kemampuan variabel independen yaitu Leverage, Perputaran Modal Kerja, Ukuran Perusahaan, dan Profitabilitas untuk menjelaskan variabel dependen yaitu Nilai perusahaan adalah $46,8 \%$ dan sisanya sebesar $53,2 \%$ dijelaskan oleh faktor-faktor lain yang tidak dimasukkan dalam model regresi ini, seperti kebijakan dividen, kepemilikan manajerial, dan pertumbuhan perusahaan.

\section{Simpulan, Keterbatasan Dan Implikasi}

Berdasarkan hasil analisis dan pembahasan yang telah dikemukakan di atas, maka dapat diambil kesimpulan bahwa leverage, perputaran modal kerja, ukuran perusahaan, dan profitabilitas secara simultan berpengaruh terhadap nilai perusahaan. Secara parsial leverage dan perputaran modal kerja tidak berpengaruh terhadap nilai perusahaan. sedangkan ukuran perusahaan dan profitabilitas secara parsial berpengaruh positif dan signifikan terhadap nilai perusahaan.

Konsep yang menjadi fokus pembahasan signaling theory yang mengatakan bahwa manajer perusahaan akan memberikan informasi sebagai sinyal yang baik bagi investor agar bersedia menanamkan modalnya di perusahaan. Namun penelitian ini belum menjelaskan lebih mendalam, bagaimana mekanisme dan tekanan fokus informasi apa saja yang menjadi prioritas utama bagi manajer untuk memberikan signal bagi investor, sehingga penelitian ini masih mengandung kekurangan pembahasan mengenai signal informasi dari sisi manajer. Disamping itu, juga belum membahas harapan investor akan investasi yang dilakukan pada industri ini. Untuk itu disarankan bagi penelitian selanjutnya menambahkan dividen sebagai variabel intervening dan membahas lebih mendalam harapan investor serta fokus utama manajer dalam menyediakan informasi.

\section{Daftar Referensi}

A. dan S. Robinhot, "Analisis Faktor-Faktor Yang Mempengaruhi Nilai Perusahaan Pada Perusahaan Farmasi Di Bursa Efek Indonesia," J. Medan, 2013.

A. F. Ishaq and N. F. Asyik, "Pengaruh Profitabilitas, Cash Position, Leverage, Dan Growth Terhadap Kebijakan Dividen," J. Ilmu Ris. Akunt., 2015.

A. Farid and D. Amboningtyas, "Analisis Dupont System Untuk Menilai Kinerja Keuangan Perusahaan (Studi Kasus Pada Pt Ace Hardware Indonesia Tahun 2011-2015)," Akuntansi, 2015.

A. Ramadona, "Pengaruh Struktur Kepemilikan Manajerial, Struktur Kepemilikan Institusional, Ukuran Perusahaan dan Leverage Terhadap Konservatisme Akuntansi," vol. Vol 3., no. No. 1, p. Halaman 2357-2370, 2016.

A. S. M. D. \& A. Wirajaya, "Pengaruh Struktur Modal, Profitabilitas dan Ukuran Perusahaan Terhadap Nilai Perusahaan," E-Journal Akunt. Univ. Yudayana, pp. 358-372, 2013.

Agus Harjito dan Martono, Manajemen Keuangan, Edisi Kedu. Yogyakarta: Ekonisia, 2017.

Andriyani, "Pengaruh Kebijakan Dividen 
Terhadap Nilai Perusahaan Pada Perusahaan Manufaktur yang Terdaftar di Bursa Efek Indonesia Tahun 20122014," Univ. Muhammadiyah Surakarta, 2017.

Aprelliya Tri Hardiana, Anggita Langgeng Wijaya, Nik Amah, 2019, Pengaruh Perputaran Modal Kerja Terhadap Nilai Perusahaan Dengan Profitabilitas Sebagai Variabel Moderasi, Seminar Inovasi Manajemen, Bisnis Dan Akuntansi I, UNIPMA, 2019

D. N. Gujarati, Dasar-dasar Ekonometrika. Jakarta: Salemba Empat, 2014.

Dwi Rachmawati \& Dahlia Br. Pinem, "Pengaruh Profitabilitas, Leverage, dan Ukuran Perusahaan Terhadap Nilai Perusahaan," Fak. Ekon. UPN "Veteran" Jakarta, 2015.

Dwi Rachmawati \& Dahlia Br. Pinem, "Pengaruh Profitabilitas, Leverage, dan Ukuran Perusahaan Terhadap Nilai Perusahaan," Fak. Ekon. UPN "Veteran" Jakarta, 2015.

Dwi Rachmawati \& Dahlia Br. Pinem, "Pengaruh Profitabilitas, Leverage, dan Ukuran Perusahaan Terhadap Nilai Perusahaan," Fak. Ekon. UPN "Veteran" Jakarta, 2015.

E. Indriyani, "Pengaruh Ukuran Perusahaan dan Profitabilitas Terhadap Nilai Perusahaan," Akuntabilitas, vol. 10, no. 2, pp. 137145, 2017, doi: 10.15408/akt.v10i2.4649.

F. Margaretha, Dasar-dasar Manajemen Keuangan. Jakarta: PT. Dian Rakyat, 2014.

Fred Weston dan Thomas Copeland, Manajemen Keuangan Jilid I, Edisi ke-9. Jakarta: Binarupa Aksara, 2015.

Grandy, Tommy dan Victori. (2016). "Pengaruh Profitabilitas, Keputusan Investasi dan Keputusan Pendanaan Terhadap Nilai Perusahaan Farmasi yang Terdaftar di BEI Periode 2011-2014". Jurnal Berkala Ilmiah Efisiensi, Volume 16 No. 04 Tahun 2016.

H. N. Ikhsan, "Pengaruh Profitabilitas, Likuiditas, Leverage, Ukuran Perusahaan dan Kebijakan Dividen Terhadap Nilai Perusahaan Pada Perusahaan BUMN Yang Terdaftar di Bursa Efek Indonesia (BEI) Pada Tahun 2014-2017," Inst. Agama Islam Negeri Surakarta, 2019.

H. N. Ikhsan, "Pengaruh Profitabilitas, Likuiditas, Leverage, Ukuran Perusahaan dan Kebijakan Dividen Terhadap Nilai Perusahaan Pada

Handayani. S, 2013, Hubungan Size, Leverage, Profitabilitas Dan Kualitas Auditor Terhadap Nilai Perusahaan Dengan Pemediasi Disclosure, Earnings Management Dan Information Asymetric Pada Industri Manufaktur, Annual Workshop, Financial Stability, And The Real Economic Performance, Bank Indonesia Jakarta, 2013

Harmono, Manajemen Keuangan Berbasis Balanced Scorecard Pendekatan Teori, Kasus dan Riset Bisnis, Edisi 1. Jakarta: Bumi Aksara, 2017.

I. S. S. Christiana Warouw, Sintje Nangoy, "Pengaruh Perputaran Modal Kerja dan Profitabilitas Terhadap Nilai Perusahaan Pada Perusahaan Farmasi Di Bursa Efek Indonesia," J. Berk. IIm. Efisiensi, vol. Volume 16, 2016.

I. S. S. Christiana Warouw, Sintje Nangoy, "Pengaruh Perputaran Modal Kerja dan Profitabilitas Terhadap Nilai Perusahaan Pada Perusahaan Farmasi Di Bursa Efek Indonesia," J. Berk. IIm. Efisiensi, vol. Volume 16, 2016.

I. S. S. Christiana Warouw, Sintje Nangoy, "Pengaruh Perputaran Modal Kerja dan Profitabilitas Terhadap Nilai Perusahaan Pada Perusahaan Farmasi Di Bursa Efek Indonesia," J. Berk. IIm. Efisiensi, vol. Volume 16, 2016.

I. S. S. Christiana Warouw, Sintje Nangoy, 2016, "Pengaruh Perputaran Modal Kerja dan Profitabilitas Terhadap Nilai Perusahaan Pada Perusahaan Farmasi Di Bursa Efek Indonesia," J. Berk. IIm. Efisiensi, vol. Volume 16, 2016.

J. A. Zacharias and D. G. Wirama, "Fakultas Ekonomi dan Bisnis Universitas Udayana, Bali , Indonesia dipakai oleh para investor dalam penilaian perusahaan . Pencapaian laba yang besar meningkatkan nilai perusahaan di mata para investor. Ketika informasi laba dapat ekonomi yang berdampak ," vol. 12, pp. 1029-1060, 2015.

Jogiyanto, Teori Portofolio dan Analisa Investasi, 8th ed. Yogyakarta: BPEE, 2016.

Jogiyanto, Teori Portofolio dan Analisa Investasi, 8th ed. Yogyakarta: BPEE, 
2016.

Kasmir, Analisis Laporan Keuangan, Cetakan ke. Jakarta: PT. Raja Grafindo Persada, 2016.

L. Liviawati, J. Wardi, and G. E. Putri, "FaktorFaktor Yang Mempengaruhi Efisiensi Perbankan Suatu Studi Pada Bank Swasta Yang Terdaftar Di Bursa Efek Indonesia," J. Akunt. Kompetif, 2019, doi:

10.35446/akuntansikompetif.v2i3.378.

L. P. Wiagustini, Dasar-dasar Manajemen Keuangan. Denpasar: Udayana University Press, 2014.

Laily Sintania Hartono, "Pengaruh Profitabilitas dan Leverage Terhadap Nilai Perusahaan Dengan Kebijakan Deviden Sebagai Variabel Moderasi," Malang, 2018.

Laily Sintania Hartono, "Pengaruh Profitabilitas dan Leverage Terhadap Nilai Perusahaan Dengan Kebijakan Deviden Sebagai Variabel Moderasi," Malang, 2018.

Laily Sintania Hartono, "Pengaruh Profitabilitas dan Leverage Terhadap Nilai Perusahaan Dengan Kebijakan Deviden Sebagai Variabel Moderasi," Malang, 2018.

Laily Sintania Hartono, "Pengaruh Profitabilitas dan Leverage Terhadap Nilai Perusahaan Dengan Kebijakan Deviden Sebagai Variabel Moderasi," Malang, 2018.

Laily Sintania Hartono, "Pengaruh Profitabilitas dan Leverage Terhadap Nilai Perusahaan Dengan Kebijakan Deviden Sebagai Variabel Moderasi," Malang, 2018.

M. Hanafi dan Abdul Halim, Analisis Laporan Keuangan, Edisi Keli. Yogyakarta: UPP STIM YKPN, 2016.

M. R. Sari, "Dampak Green Accounting Terhadap Kinerja Keuangan," 1 Desember, 2016.

Mafira Haidar, "Pengaruh Profitabilitas, Ukuran Perusahaan, Kebijakan Hutang dan Struktur Modal Terhadap Nilai Perusahaan Sektor Industri Barang Konsumsi," Surabaya, 2019.

Mafira Haidar, "Pengaruh Profitabilitas, Ukuran Perusahaan, Kebijakan Hutang dan Struktur Modal Terhadap Nilai Perusahaan Sektor Industri Barang Konsumsi," Surabaya, 2019.

N. K. A. S. \& N. P. A. Darmayanti, "Pengaruh Profitabilitas, Likuiditas, Pertumbuhan, dan Investment Opportunity Set
Terhadap Nilai Perusahaan," E-Jurnal Manaj. Unud, vol. Vol. 5, no. Nol. 7, 2016.

Nur Indah Sari, "Pengaruh Ukuran Perusahaan, Profitabilitas, dan Leverage Terhadap Nilai Perusahaan pada Perusahaan Property and Real Estate yang Terdaftar di Bursa Efek Indonesia Tahun 20142015," 2018.

P. A. \& P. Pakarti, Pengantar Pasar Modal (Edisi Revisi). Jakarta: Rineka Cipta, 2008.

P. M. N. \& P. V. Lestari, "Pengaruh Ukuran Perusahaan, Leverage, dan Profitabilitas Terhadap Nilai Perusahaan Pada Sektor Properti dan Real Estate," E-Jurnal Manaj. Unud, vol. Vol. 5, no. No. 9, 2016.

P. M. N. \& P. V. Lestari, "Pengaruh Ukuran Perusahaan, Leverage, dan Profitabilitas Terhadap Nilai Perusahaan Pada Sektor Properti dan Real Estate," E-Jurnal Manaj. Unud, vol. Vol. 5, no. No. 9, 2016.

Randhy Agusentoso, "Pengaruh Struktur Modal, Perputaran Modal Kerja, Dan Profitabilitas Terhadap Nilai Perusahaan (PBV)," J. Pendidikan, Ekon. dan Bisnis, vol. 1, no. iv, 2017.

Randhy Agusentoso, "Pengaruh Struktur Modal, Perputaran Modal Kerja, Dan Profitabilitas Terhadap Nilai Perusahaan (PBV)," J. Pendidikan, Ekon. dan Bisnis, vol. 1, no. iv, 2017.

Randhy Agusentoso, "Pengaruh Struktur Modal, Perputaran Modal Kerja, Dan Profitabilitas Terhadap Nilai Perusahaan (PBV)," J. Pendidikan, Ekon. dan Bisnis, vol. 1, no. iv, 2017.

Randhy Agusentoso, "Pengaruh Struktur Modal, Perputaran Modal Kerja, Dan Profitabilitas Terhadap Nilai Perusahaan (PBV)," J. Pendidikan, Ekon. dan Bisnis, vol. 1, no. iv, 2017.

Randhy Agusentoso, "Pengaruh Struktur Modal, Perputaran Modal Kerja, Dan Profitabilitas Terhadap Nilai Perusahaan (PBV)," J. Pendidikan, Ekon. dan Bisnis, vol. 1, no. iv, 2017.

Randhy Agusentoso, "Pengaruh Struktur Modal, Perputaran Modal Kerja, Dan Profitabilitas Terhadap Nilai Perusahaan (PBV)," J. Pendidikan, Ekon. dan Bisnis, vol. 1, no. iv, 2017. 
Randhy Agusentoso, "Pengaruh Struktur Modal, Perputaran Modal Kerja, Dan Profitabilitas Terhadap Nilai Perusahaan (PBV)," J. Pendidikan, Ekon. dan Bisnis, vol. 1, no. iv, 2017.

Randhy Agusentoso, "Pengaruh Struktur Modal, Perputaran Modal Kerja, Dan Profitabilitas Terhadap Nilai Perusahaan (PBV)," J. Pendidikan, Ekon. dan Bisnis, vol. 1, no. iv, 2017.

S Handayani, 2013, Determinan Karakteristik Perusahaan terhadap Earnings Management Dengan Pemediasi Disclosure, ERC dan Information Asymetric pada Perusahaan Manufaktur di Indonesia, Prosiding Seminar Nasional FMI 05, 2013.

S Handayani, 2013, Determinan Karakteristik Perusahaan terhadap Earnings Management Dengan Pemediasi Disclosure, ERC dan Information Asymetric pada Perusahaan Manufaktur di Indonesia, Prosiding Seminar Nasional FMI 05, 2013.

S Handayani, Abdurrahman, 2014, Earning Management dan Relevansi Informasi Akuntansi : Pendekatan Motivasi Signalling dan Opportunistik, Simposium Nasional Akuntansi XVII, Mataram, 2014

S. dan E. P. Husnan, Dasar-dasar manajemen Keuangan, Edisi Ketu. Yogyakarta: UPP STIM YKPN, 2015.

S. Munawir, Analisa Laporan Keuangan. Yogyakarta: Liberty, 2015.

Seviana Widia Putri, "Pengaruh Kebijakn Dividen, Leverage, Ukuran Perusahaan, Kepemilikan Manajerial, Terhadap Nilai Perusahaan," 2018.

Seviana Widia Putri, "Pengaruh Kebijakn Dividen, Leverage, Ukuran Perusahaan, Kepemilikan Manajerial, Terhadap Nilai Perusahaan," 2018.

Suwardika, I. N. A., and I. K. Mustanda. "Pengaruh Leverage, Ukuran Perusahaan, Pertumbuhan Perusahaan, dan Profitabilitas terhadap Nilai Perusahaan pada Perusahaan Properti." E-Jurnal Manajemen Universitas Udayana, vol. 6, no. 3, 2017

Suwardika, I. N. A., and I. K. Mustanda. "Pengaruh Leverage, Ukuran Perusahaan, Pertumbuhan Perusahaan, dan Profitabilitas terhadap Nilai
Perusahaan pada Perusahaan Properti." E-Jurnal Manajemen Universitas Udayana, vol. 6, no. 3, 2017.

Suwardika, I. N. A., and I. K. Mustanda. "Pengaruh Leverage, Ukuran Perusahaan, Pertumbuhan Perusahaan, dan Profitabilitas terhadap Nilai Perusahaan pada Perusahaan Properti." E-Jurnal Manajemen Universitas Udayana, vol. 6, no. 3, 2017.

Suwardika, I. N. A., and I. K. Mustanda. "Pengaruh Leverage, Ukuran Perusahaan, Pertumbuhan Perusahaan, dan Profitabilitas terhadap Nilai Perusahaan pada Perusahaan Properti." E-Jurnal Manajemen Universitas Udayana, vol. 6, no. 3, 2017.

Wawan Cahyo Nugroho, Fadlil Abdani, 2017, Investasi dalam Islam 108 El-Muhasaba, Vol.8, No.1, Januari 2017

Yuswandy Yoedy, "Analisis Pengaruh Harga Minyak Dunia, Harga Emas Dunia, Nilai Tukar Rupiah Terhadap USD dan IHSG Terhadap Return Saham," J. Cap. Mark. Bank., 2013. 